Article

\title{
The Gendered Space of the "Oriental Vatican"-Zi-ka-wei, the French Jesuits and the Evolution of Papal Diplomacy
}

\author{
Wei Mo ${ }^{1,2}$ \\ 1 Centre for Studies in Religion and Society, University of Victoria, 3800 Finnerty Road, Victoria, BC V8P 5C2, \\ Canada; weimo@uvic.ca \\ 2 College of Humanities and Communications, Shanghai Normal University, No.100 Guilin Rd., Shanghai \\ 200234, China
}

Received: 3 August 2018; Accepted: 11 September 2018; Published: 14 September 2018

\begin{abstract}
In a global context, the story of the Jesuit compound in Shanghai, since its establishment by French Jesuits in 1847, reflected not only conflicts between rival powers in Europe but also the fight for their interests in the Eastern world. The female Catholic orders at the east bank of Zi-ka-wei compound provided a unique window approaching the complexity. The Pope, who was stuck without legal status in the Vatican after 1861, was also seeking the chance to save the authority of the Church in the face of questions regarding the extent of his temporal power and the status of Rome in the context of Italian unification. As in the Reformation, a break-through in the east seemed to offer a solution for losses in Europe. However, the Jesuits to the East in the late 19th century were not only troops working and fighting on behalf of the Pope; their identities under the French Protectorate added complexity to an already complicated story involving not just the Church, but the course of world history. Locating the Jesuit-affiliated women and children hospice in the French Concession but outside the Zi-ka-wei compound was a result of how different conflicts played themselves out.
\end{abstract}

Keywords: Jesuits; French Protectorate; female orders; Zi-ka-wei; Roman Question

\section{Introduction}

This paper has four objectives. First, it seeks to explain the site selection of a major Jesuit compound in Shanghai after the Jesuits' restoration and return to China in the new nineteenth century global context. Second, it analyzes the compound's carefully planned layout, which was based on gender and the division of various responsibilities. Third, this paper highlights the connection between the French Religious Protectorate in China and the prosperity of the Catholic compound and illustrates that the decline in French power and instability in Europe provided the Pope with more responsibilities for the Catholic mission's agenda in China. Fourth, the paper analyzes how a particular female Catholic institution came to be located where it was.

From the map of Zi-ka-wei (Xu Jia Hui, 徐家匯) Area in 1937 (Figure 1), we can see before us a mature and complete Catholic compound with fully functioning institutions under Jesuit leadership. Associated with the Jesuits in the compound were female religious of the Helpers of the Holy Souls, the Présentadines, the Josephines and the Discalced Carmelite Nuns. The name of this area, $\mathrm{Zi}-\mathrm{ka}-w e i$, is a Romanized spelling of the pronunciation of $\mathrm{Xu}$ Jia Hui in Shanghai dialect. Such a completed compound was a symbol of the gendered organization of Chinese Catholicism had, since its establishment in the mid-19th century. A Chinese Catholic constituency, made up of survivors of several decades of the court repression, was an unalloyed blessing for the Church. Zi-ka-wei stood as a model, showing that a uniform structure for the Chinese Catholic church was not a distant prospect. 
Yet, while the Pope tried to restructure the missions, another European power-the French-usurped the Pope's supervisory role over the whole of Catholicism in China.

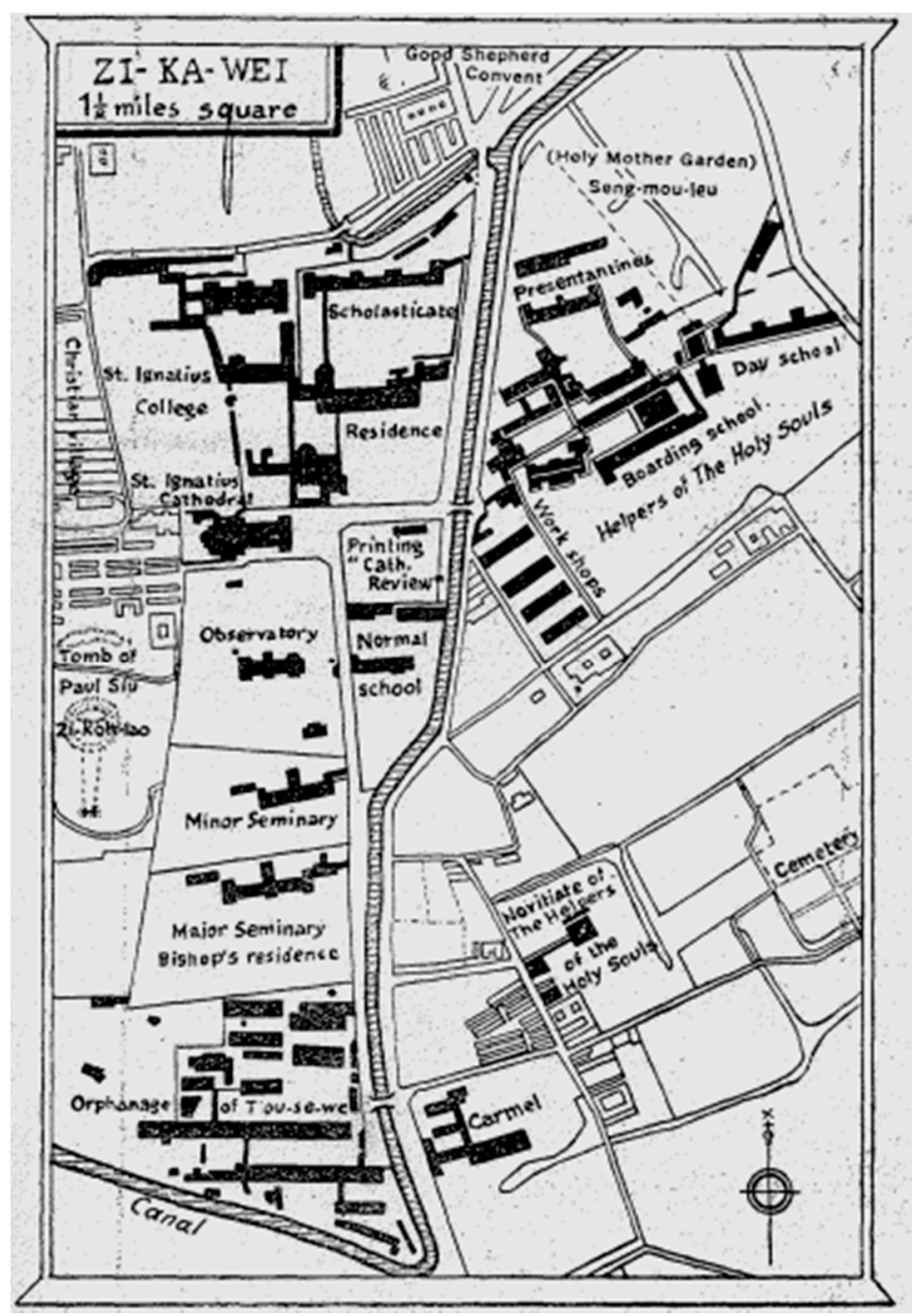

Figure 1. Map of Zi-ka-wei, see (Song 2005).

In a global context, the story of the Jesuit compound over the next century reflected not only conflicts between rival powers in Europe but also the fight for their interests in the Eastern world. The Pope, who was stuck without legal status in the Vatican after 1861, was also seeking the chance to save the authority of the Church in the face of questions regarding the extent of his temporal power and the status of Rome in the context of Italian unification. As in the Reformation, a break-through in the east seemed to offer a solution for losses in Europe. However, the Jesuits to the East in the late 19th century were not only troops working and fighting on behalf of the Pope; their identities under the French Protectorate added complexity to an already complicated story involving not just the Church, but the course of world history.

Those missionaries who arrived in the 1930s praised the magnificence of the Zi-ka-wei compound as the "Oriental Vatican". There are various ways to approach this issue; here I want to throw light on the gendered layout of this Catholic institutions by examining the political and diplomatic development that were taking place. In particular, I want to consider the reason the Hospice of the Sisters of the Good Shepherd (善牧院) was not situated inside Jesuit Zi-ka-wei compound. 


\section{Site Selection and Structure of the Jesuit Compound in Shanghai}

The building of the Catholic compound in Zi-ka-wei by the "New Jesuits"1 of the order's Paris Province $^{2}$ began in $1847 .^{3}$ At this time, there were already Catholic communities in other parts of Shanghai, such as those anchored in the Jingyi Tang (敬一堂) and St. Joseph Cathedral, both in the Chinese in the Qing-controlled parts of the city (華界). The French Jesuits could have established a compound based on one of those; however, they were determined to construct an independent compound from scratch, without reliance on the local community. Moreover, the Jesuits would never take a risk on such a huge project without initially having detailed plans that met their specific purposes. Their thoroughgoing selection of an appropriate site finally settled on the southwest end of Zi-ka-wei, the suburban area of Shanghai. The reasons for their selection were multifold, but can be generalized into five major points.

The first and most superficial reason was stated in their official claim of the necessity of a new residence. They argued that the humidity of the former compound, situated in the rural area, Hengtang of Qingpu County (青浦縣横塘), discomforted the majority of the Jesuits from France. Their inability to the dampness in the old place motivated their expansion outwards.

Secondly, they felt that the new site should have convenient access to the central part of the city and especially to the French Concession. With the help of the natural rivers and artificial canals, Zi-ka-wei took advantage of its geographical features for the purpose of city access. Thus, "Hui" (匯, which represents the confluence of multiple waterways) was also retained in the name of the delta place and the compound.

More importantly, however, the fact that there was a remnant Catholic population in this specific local area was decisive. The $\mathrm{Xu}$ clan, a strong local Catholic family, had been residing there since the 16th century because their famous ancestor Xu Guangqi (徐光啓, 1562-1633), who had been a native of Shanghai, was buried in Zi-ka-wei where his Catholic descendants kept the tomb. Xu Guangqi, who had been a Grand Secretary (文淵閣大學士) in the Ming (明) court, was a significant helper and promoter of Matteo Ricci (利瑪寶, 1553-1610) and the first of the Jesuit "generation of Giants"4 Therefore, the words “Xu Jia" (徐家, which literally means the Xu's family) was also kept in the name of the Catholic compound, indicating the family's pride at on being descended from the very first group of converts 5 .

Fourth: related to the previous point, was the fact that the Jesuits intended to make the new compound the scientific centre of the Jiang-nan religion. Xu Guangqi himself had used the site of the new compound for agriculture experiment that formed a base for his major agricultural treatise the Nongzhengquanshu or "Complete treatise on agricultural administration" (《農政全書》). In addition, $\mathrm{Xu}$ Guangqi himself had extensive mathematical and astronomical research interests and initiated a major translation project in these area. Such interests made the Zi-ka-wei site highly suitable for the

1 The Jesuits had been suppressed globally by the papal brief Dominus ac Redemptor (21 July, 1773). After seven decades, the order was restored. To designate the two generations before and after the restoration, the term "New Jesuit" was invented, but it most often refers to those who worked after the restoration in particular. See the entry term "China" (Worcester 2017, p. 164).

2 As a territorial division of the Catholic Church in apostolic vicariates or perfectures in the 19th century, Jesuits ultimately served in nine different areas, led by Shanghai staffed by French Jesuits of the Paris province. See (Gernet 1985, p. 17).

3 It took some time after the restoration of the Society of Jesus in 1814 before New Jesuits were sent to China. After multiple requests by Chinese Christians, the first three French Jesuits led by Claude Gotteland (南格祿, 1803-1856) finally arrived in China in 1842. They arrived in Hengtang at first and built their residence and 5 years later, they were able to move into the central part of Shanghai. It was in 1847 that construction on the Jesuit Residence in Zi-ka-wei was started.

4 "Generation of Giants" was a specified term for the first generation of Jesuits who worked in China from 1582 to 1775, see (Dunne 1962).

5 On the relationship between the New Jesuits and the remnant old communities of Catholics who had survived since the eighteenth century, "Given the relative paucity of European personnel, it is important to note that the number of Catholic faithful, in spite of the periodic persecutions, had increased by about 100,000 by the middle of the nineteenth century. At the same time, priestly duties were performed primarily by the Chinese clergy. As a matter of fact, Chinese Catholics had developed their own patterns of church life." See (d'Elia 1927, p. 50). 
New Jesuit scientific centre including in particular the astronomical Observatory and the Museum of Natural History then were planned for construction.

Fifthly and perhaps the most critically, the relatively low cost of land in this suburb, to some extent ensured the scale and potential expansion of the compound both immediately and into the future. Certainly, the donation of land by the local Catholics also mitigated the burden for the Church. At the same time, the "official" contribution from the French side was more imperial. The Sino-French treaty (Treaty of Huangpu 《黃埔條約》, 1844) allowed the French to establish churches, hospices, schools, and cemeteries in five designated ports, including Shanghai and Tianjin, which were already opened for foreign residence, trade, and naval vessels by the previous British treaties. The French were granted in their own treaty immunity from prosecution by Chinese authorities (extra-territoriality, or more precisely, consular jurisdiction) ${ }^{6}$. Despite numerous occurances in the 1840s and 1850s of missionaries going outside the designated areas, French authorities never attempted to enforce restrictions on the missionaries ${ }^{7}$. The continuing pattern of the emerging French Religious Protectorate over Roman Catholics (as laid out in the French Treaty of Tianjin ${ }^{8}$ 《天津條約》, 1858 and the Sino-French Convention of Beijing ${ }^{9}$ 《北京條約》, 1860) helped the missionaries to overstep the boundaries of where they were permitted to travel. The Protectorate prioritized the land used for French religious orders at a lower price. The diplomatic and military muscle of the French was what the French Jesuits were desperate for.

French Jesuit-run Jiang-nan, covering two provinces and including Shanghai centered by Zi-ka-wei, had by far the largest investments $(6,924,303$ gold dollars, or about seventy million French francs)- over three and a half times the next in line. Its expenses were also high, because of its size and its many priests and costly institutions. The selection of Zi-ka-wei as the centre of the Jesuit presence in China, and perhaps even in the whole of East Asia, was acceptable by all sides in the mid-late 19th century.

\section{The Compound and Protectorate under the Sino-French Conventions}

The practice based on the treaties was critical in holding together the transnational pretensions of the French Religious Protectorate. When venturing beyond the five major ports, all the Catholic missionaries ${ }^{10}$ were formally presented to the Chinese world as protégés of the French state. Increasingly, French authorities called on the missions to establish more schools where the French language and French learning would be taught. They were also encouraged to found more hospitals, which the missions would manage but which would not be staffed only with religious personnel, as a way of displaying French science to China. Zi-ka-wei under the supervision and leadership of French Jesuits was the most vivid example of the expansion of Catholic missionary interests in the Qing (清) Empire.

6 Like the British and Americans, the French were supposed to be confined to the environs of these five treaty ports. However, the French treaty specified that, if a French person violated this restriction and "proceeded far into the interior", they should be conducted unharmed to the French consul in the nearest treaty port. Although it made no mention of missionaries, they were the object of interest here. See (China. Hai guan zong shui wu si shu 1917, pp. 771-813).

7 Restrictions embodied in a formal Sino-Franco treaty and agreed to in discussion about a Chinese toleration pronouncement. See (Gernet 1985, p. 83).

8 Under the Treaty of Tianjin, special passports were issued as envisioned in Articles 8 and 13. See Tableau des Traité, Conventions et arrangements divers, relatifs au Protectorat de La Franc sur les chrétientés en Chine. 10 May 1900, file box 59. Archives Diplomatiques de Nantes, documents of the French legation in Beijing. Paris and (Cannone 1987, p. 116).

9 The Beijing Convention, another Franco-Chinese treaty, was imposed in 1860 under the threat of military continued occupation of the imperial capital, additions were made that opened the door to endless complications and conflict. Article 6 of the convention treated Christians and their religion. Part of the reason that the article led to so much controversy was that it treated property, never an easy topic. Another part of the problem was the ambiguity engendered by differing texts. The French and Chinese version of Article 6 of the Beijing Convention were conspicuously divergent in phraseology and even in content.

10 Missionaries as Italian, Belgian, German, Austrian, Spanish, Portuguese, Dutch, and Irish, as well as French. 
Reviewing the whole structure from the map, the Zi-ka-wei compound was generally divided by the Zhaojia Canal (肇嘉), which operated as the central axis between the west and east banks. The layout was strictly arranged according to the division of responsibilities by gender. The west bank was lined up from the top to the bottom with St. Ignace College, the Scholasticate, the Jesuit residence, the Zi-ka-wei library, the St. Ignatius Cathedral, the astronomical Observatory, the Museum of Natural History, the Major and Minor Seminaries and the T'ou-sè-wè Orphanage ${ }^{11}$ (土山灣孤兒院). All of these institutions were without exception operated by and for male members of the compound, while the east side was totally reserved for female members from the Carmelite Convent, the Notre Dame complex and the Hospice of the Sisters of the Good Shepherd. Most of the supporting staff were French missionaries. By virtue of their pivotal position under French power, the political fact of being French was the most prominent asset in the Zi-ka-wei compound. How curious it was that France, which was such a model of modern nationalism, should have sponsored in China such a subversion of the sacred relationship of citizen and the country. Although French power in China was a source of contention with other states, which openly complained to the Pope especially during the peak decades (1840s-1914) of French power, the response from the Vatican was one of indifference. Between the Pope and the French there was "a sort of tacit mandate" entrusting the defense of Catholic interests in China to France. The long official French memo continued:

Apart from that, [there is] no right, no strict obligation in the basis of our protectorate. Nothing binds Catholic missionaries to our operation. If all, from whatever countries they hail, have gave up to now resorted to French protection, it is because this protection was the best to be offered them, without distinction of nationalities, strongly enough organized to be efficacious with the Chinese authorities and constituting an assemblage of advantages substantial enough to connect the missionaries to it. Thus our protectorate became a tradition, and the beneficiaries have never had reason to complain about it. ${ }^{12}$

In the 1930s, a grand Catholic compound was "honored" as the "Oriental Vatican"13 frequently. In addition, the following reports from the Church followed this trend without any hesitation. Interestingly, however, a more accurate comparison might have been between the Vatican and either Goa, ${ }^{14}$ the entry point of Jesuits in India that developed into the Jesuits' mission centre in 16th century Asia, or Macau, ${ }^{15}$ the long serving base of operation for the missions in China and Japan during 17th and 18th century. What, then, was the intention behind the compliment? An inconspicuous institution, the Hospice of the Sisters of the Good Shepherd, standing atop the east bank of the compound, might offer an explanation as the Hospice itself was also established as a refraction of a trend in global history.

11 Tòou-sè-wè was also a Romanized spelling of the pronunciation in Shanghai dialect.

12 Crise de notre Protectorat religieux en Chine (1886-1892). Archives Diplomatiques de Nantes, documents of the French legation in Beijing, file box 59, which states "The memorandum is not dated. Internal evidence suggests that it was written about 1898. Since one German-staffed vicariate had already departed from the French Protectorate, the reference to 'all' missionaries was not exact." Quoted in (Young 2013, p. 42).

13 See (Xiao 1997, p. 45).

14 Goa was the beginning point of the early Jesuits as they expanded into the Indian subcontinent, and later it was the seat of the first Jesuit province to be established in Asia. Francis Xavier led the way in 1542 at the request of the Portuguese king, under whose patronage (the Padroado) the Pope had entrusted the mission. Jesuits ministered to the native population in Goa and its environs, quickly becoming a base for missions throughout India. See (Pfister 1932, pp. 95-102).

15 Many notable Jesuits spent time in Macau. This territory was established by the Portuguese in 1557 for the purpose of exploration and trade in China. Despite its small size, its prime location on a tip of a peninsula on the southern Chinese coastline facilitated rapid population growth. Most early inhabitants were Portuguese merchants and their families; they were rapidly joined by various religious orders, including the Jesuits. The Christian population more than doubled, from 400 to 1000, in the first twenty-five years of the settlement's existence. A Jesuit residence was built in 1565 and Jesuit official visitor Alessandro Valignano (範禮安, 1539-1606) arrived in 1577. Ten months spent awaiting favorable weather for sailing to Japan allowed him time to observe, evaluate and establish the policy of cultural accommodation. Michele Ruggieri (羅明堅, 1543-1607) arrived in Macau two years later, and Matteo Ricci in 1583. They began studying the Chinese language and preparing for their historic mission work there. See (Brockey 2007). 


\section{Female Orders in Zi-ka-wei as an Echo of Catholic Evangelistic Energy}

Within Catholicism, groups of women, renouncing marriage and living either with their birth-family or in small self-organized groups, formed communities centered on a chapel, taught children prayers and doctrine, helped the sick and the dying, baptized babies, and cared for their local chapel. Such women became known in China as Virgins (tongzhennü 童貞女). They would eventually be found in most parts of the country, though with considerable local variation. These women attracted the attention of the missionaries, Jesuits mainly, who were reestablishing themselves in Jiang-nan area (south of the Yangtze River, 江南地區) after the Opium Wars. ${ }^{16}$

The formal rules for women's social behavior could be extremely restrictive in late imperial and under the Republic of China. Female leadership or presence at any mixed-gender setting outside the family could be tarred with the brush of potential sexual promiscuity. Yet it is also the case that leadership roles for Chinese women in religious practice were not unheard of. Female spirit mediums and shamans were common in folk religious practice among the Chinese. Nonetheless, the returning Jesuits were distinctly hostile to the fact that they found women exercising leadership in remnant Catholic communities from the strong Catholic tradition of male supremacy in the Church matters. It would seem that this initial hostility of the returning missionaries toward this assertiveness by Catholic women in the Jiang-nan arose as much as anything from an anxiety about the difficulty of controlling these hidden Catholic groups. French missionaries asserted their authority over the Virgins without abolishing the practice. Already in the 18th century, they had rules, approved by Rome, for the work and living circumstances of these women. It was in part the evident departures from those rules in Jiang-nan that alarmed the returning Jesuits. One tactic was to reorganize the Virgins in conventual religious congregations, with various designations: the Présentadines (Association of the Presentation of Blessed Virgin, 貞女獻堂會), the Josephines (若瑟會), and so on.

As we have seen, the east bank of the Catholic Compound in Zi-ka-wei was designated for female religious congregations. The Notre Dame complex, under the management of the Helpers of the Holy Souls (Auxiliatrices des âmes du Purgatoire, 拯望會), who were French sisters invited by the Jesuits from Paris, had the most popularity and fame. When the Jesuits had just launched their plan of establishing the Zi-ka-wei compound, the Helpers were their first option for taking on lead administration over the indigenous Catholic female orders, whose service and training were less organized but more practical for local residents. The Notre Dame complex was initiated in 1855 under the leadership of the Helpers and grew gradually by increasing the number of affiliated institutions with comprehensive divisions and different emphases ${ }^{17}$. The achievements of the Virgins movement ${ }^{18}$ were a valuable addition to Catholic evangelizing efforts. A Jesuit missionary expressed his appreciation of the female institutions:

The Virgins, because of their instruction, are especially in ascendancy. These fine girls, who have renounced marriage to serve the cause of religion and have spent years studying, render us immense services. Chinese women, who never engage in studies, look on them as oracles. In the Catholic communities where they [the Virgins] sojourn, they train girls, preach, catechize, lead prayers, prepare the ille [sic] for death, keep the church clean, etc.

16 Wrote the chronicler of the Jesuits' return to Jiang-nan: "In more than one village, a Virgin had usurped the functions of administrator. Almost everywhere they led the chanting of prayers at the church, gave pious readings, and admonished delinquents." See (La Servière 1925) The English translation was quoted from (Young 2013, p. 20).

17 Some of the unmarried Jiang-nan laywomen were encouraged to organise themselves into an indigenous religious association. Virgins of the Presentation did not take the vows, was under the authority of the French mission superior to instruct and form the girls. The French sisters took charge of girl orphans and pupils at the Notre Dame. In this context, it can be argued that Virgins was coming into contact and working with foreign sisters and becoming attracted to a life in a communal religious environment. See (Tiedemann 2010, pp. 587-99).

18 Direct Catholic evangelization among women continued to be undertaken by the "institutes of virgins", namely unwed Chinese Catholic women who had dedicated their lives to God and the mission, as well as by the emerging diocesan-level Chinese sisterhood ... See (Tiedemann 2010, pp. 319-21). 
They are generally from the thirties to forty years old. They always have with them one or two orphans, who follow them. We give to one Virgin the equivalent of eight fr. per month. With that they have to feed themselves. ${ }^{19}$

In addition to the European missionary sisters, the first group of nuns arrived in 1869. In that year, French Discalced Carmelite Nuns established their convent at the opposite side of Tòu-sè-wè across the Canal. In contrast to the Virgins and the Helpers, the nuns led rather more cloistered lives and were primarily involved in the contemplative apostolate. Curiously, the Hospice of the Sisters of the Good Shepherd was settled half a century later in 1933 and located at the rim of far north end of the whole compound.

This new institution relatively distant from the core part of the compound would become a window to disclose bigger trends in international relations as well as in mission strategy. I will turn now to consider some of those larger developments in Europe and in China.

\section{The Pope's Absence in Global Instabilities, and the Fall of Ecclesiastical France}

By the year 1870, the Notre Dame complex was running successfully under the Virgins and the Carmelite Sisters. Yet this year was also a turning point in global history. The Franco-Prussian War (1870-1871) resulted in the collapse of the Second French Empire and in the formation of both the French Third Republic and the German Empire ${ }^{20}$. The unification of Italy occurred in the same year, due to Rome and the Papal States losing the protection and force of French troops since 1861 who were engaged with the Prussian Army. The dispute regarding the "temporal power" of the Pope and the status of Rome as a civil territory in the context of Italian Resorgimento (Italian unification) was named the Roman Question (Italian: Questione romana) ${ }^{21}$. In China, the Tianjin Massacre (Tianjin Church Incident 天津教案) took place, becoming one of the most important anti-Catholic incidents of the late Qing dynasty, involving attacks on French Catholic priests and nuns, violent belligerence from French diplomats, and armed foreign intervention in Tianjin.

Before 1870, Catholics in France were a major financial supporter of the global growth of Catholic missions in the 19th century. Although there were funding branches throughout various European countries, from 1822-1872, two-thirds of all funds for global Catholic mission work came from French contributions. The rate of departures of Catholic missionaries from France steadily increased from

19 R.G. Tiederman indicates that the Catholic Virgins were generally supported by their families, implying a certain affluence, but that others might support themselves by labor, like textile production, or might receive mission subsidies. See (Menegon 2009, pp. 332-42).

20 With the French garrison gone, widespread public demonstrations demanded that the Italian government take Rome. But Rome remained under French protection on paper, therefore an attack would still have been regarded as an act of war against the French Empire. Furthermore, although Prussia was at war with France, it had gone to war in an uneasy alliance with the Catholic South German states that it had fought against (alongside Italy) just four years earlier. It was only after the surrender of Napoleon and his army at the Battle of Sedan the situation changed radically. The French Emperor was deposed and forced into exile. The best French units had been captured by the Germans, who quickly followed up their success at Sedan by marching on Paris. Faced with a pressing need to defend its capital with its remaining forces, the new French government was clearly not in a military position to retaliate against Italy. In any event, the new government was far less sympathetic to the Holy See and did not possess the political will to protect the Pope's position. Finally, with the French government on a more democratic footing and the seemingly harsh German peace terms becoming public knowledge, Italian public opinion shifted sharply away from the German side in favour of France. With that development, the prospect of a conflict on the Italian peninsula provoking foreign intervention all but vanished. See (Howard 1991, p. 123).

21 The capture of Rome (Italian: Presa di Roma) on 20 September 1870 was the final event of the long process of Italian unification known as the Risorgimento, marking both the final defeat of the Papal States under Pope Pius IX and the unification of the Italian peninsula under King Victor Emmanuel II of the House of Savoy. The capture of Rome ended the approximate 1116-year reign (AD 754 to 1870) of the Papal States under the Holy See and is today widely memorialized throughout Italy with the street name in virtually every town of any size. As nationalism swept the Italian Peninsula in the 19th century, efforts to unify Italy were blocked in part by the Papal States, which ran through the middle of the peninsula and included the ancient capital of Rome. The Papal States were able to fend off efforts to conquer them largely through the pope's influence over the leaders of stronger European powers such as France and Austria. When Rome was eventually taken, the Italian government reportedly intended to let the pope keep the part of Rome west of the Tiber called the Leonine City as a small remaining Papal State, but Pius IX refused. One week after entering Rome, the Italian troops had taken the entire city save for the Apostolic Palace; the inhabitants of the city then voted to join Italy. See (Schapiro 1921, p. 160). 
1830 on, including priests, brothers, and members of female religious orders. In China, where French missionaries had already been a substantial fraction, the French soon became a strong majority of all Catholic missionaries_-as much as seventy percent or more. When, in 1870, the first Vatican Council defined papal infallibility and affirmed the immediate jurisdiction of the pope throughout the Catholic Church, anticlerical zeal was stoked in France and elsewhere. The Franco-Prussian War saw the capture of Napoleon III himself by Prussian forces and later his departure into exile. In Paris, the short-lived Commune seemed for a time to revive the Terror of 1793-1794 and its violent anticlericalism. In May 1871 the archbishop of Paris was executed, as were five Jesuits. The establishment of the Third Republic, with its deal of a muscular laïcité, would lead, in 1880, to a decree dissolving the Society of Jesus in France. Of the nearly 3000 French Jesuits at the time, approximately a third were young Jesuits in formation. For them, houses of studies were established outside France, on the English island of Jersey, and in Belgium and Spain. In France, some of the Jesuit colleges continued to function with Jesuit staffing, but with ownership of property and governance of the institutions legally conferred on diocesan priests or laity.

From 1880 to 1914, most French Jesuits took a dim view of the French Republic and pessimistic view of the modern world. Many longed for restoration of the French monarchy. However, Pope Leo XIII (1878-1903) called for French Catholics to accept a republican form of civil government, a call that fell on largely deaf ears, Jesuit and others. In his 1891 encyclical Rerum novarum ${ }^{22}$, Leo appealed for fair wages and humane working conditions for workers, for the natural right of workers to unionize to be respected, and for the state to intervene in the ceremony to protect workers from unfair treatment. Action Populaire, founded by Jesuits in 1903 in Reims, echoed Leo's response to the Industrial Revolution, but many French Jesuits sided with the wealthy elite, not with the poor and workers. When the Jewish military officer Alfred Dreyfus ${ }^{23}$ (1859-1935) was accused of treason, more than a few French Jesuits embraced a tirade of anti-Semitic polemics ${ }^{24}$. The French 1901 law on associations made it very difficult for a religious order to function in France; the Society of Jesus became one of many French orders living and working in exile ${ }^{25}$.

However, the failure of the French in the war with Prussia and the unification of Italy sparked the entry of both Germany and Italy into competition for the role of Catholic protection, while the constant stream of Church Incidents definitively weakened the French for the rest of the century and beyond.

The French Catholic compound of Zi-ka-wei as the centre of Catholicism in China quietly moved to prevent upheaval. The expansion that took place remained within the inner structure of the existing layout, however.

The spring of 1900 inflamed China and grabbed the world's attention, due to the Boxer Rebellion ${ }^{26}$, which led to the intervention of eight-foreign powers (八國聯軍). The climactic events of the Boxer

22 Rerum novarum (from its opening words, with the direct translation of the Latin meaning "of the new things"), or Rights and Duties of Capital and Labor, was an encyclical issued by Pope Leo XIII on 15 May 1891. It was an open letter, passed to all Catholic Patriarchs, Primates, Archbishops and bishops, that addressed the condition of the working classes. It discussed the relationships and mutual duties between labor and capital, as well as government and its citizens. Of primary concern was the need for some amelioration of "The misery and wretchedness pressing so unjustly on the majority of the working class." It supported the rights of labor to form unions, rejected socialism and unrestricted capitalism, whilst affirming the right to private property. See (Molony and Thompson 2006, pp. 148-49).

23 Alfred Dreyfus was a French Jewish artillery officer whose trial and conviction in 1894 on charges of treason became one of the tensest political dramas in modern French history with a wide echo in all Europe. Known today as the Dreyfus Affair, the incident eventually ended with Dreyfus's complete exoneration.

24 See the entry "France" (Worcester 2017, p. 310).

25 The big crisis in the relations with the new Republic came already in 1880 . They weren't exactly forbidden to be Jesuits, but they also not recognized as a legal association. Perhaps most significantly, they were banned from they were teaching and their educational institutions were abolished. Many therefore went abroad to work, and those that stayed just had the status of private citizens. A particular interesting point was that in the 1878 nearly one third of all Jesuits were French, and an even larger proportion of Jesuit missionaries were French. See (Lacouture 1991, p. 250).

26 Recent scholarship has preferred the term Boxer Uprising (leaving open the question of the relationship between the movement and the government), or the Boxer War (at its climax, there was a war between the Qing court and an assemblage of eight allied countries). See (Waley-Cohen 2006; Brook and Blue 1999). 
summer overwhelmed the French Religious Protectorate. It had already been somewhat battered even before the Boxers: by the German defection, by vociferous Italian discontent with a French-run system, by possible undermining from other "spheres of influence" (could French protection of Catholics persist in areas of the country where some other foreign power claimed priority in all things?) ${ }^{27}$, and by doubts within the French establishment regarding the legality of it all. One of the consequences of the Boxer Uprising was the sustained critical evaluation of the missionary enterprise. Would the limits of French protection, so evident in the Boxer Rebellion, vitiate its future in the eyes of its crucial constituency, the Catholic missionaries?

Following the Boxer Rebellion, Émile Combes, an anti-clericalist and a French statesman as a former member of a leftist cabinet, began pushing an anti-clerical agenda and guided the initial steps towards the full legal separation of church and state of France, which was finally passed the year 1905. Would the French Protectorate survive the Separation Law of 1905? ${ }^{28}$ The French consul-general in Shanghai warned against the possible consequences of weakening officialdom in both ends of the Protectorate. When the tensions between France and the Vatican were served since the beginning of the 20th century, the foreign minister instructed his representative in China that French rights in China were based on treaties and that it remained no change in existing instructions. ${ }^{29}$ As an echo to this political blow, the French Religious Protectorate in China was challenged by both Germany and Italy. At the same time, France persisted in trying to assert its Religious Protectorate and in seeking the adherence to it of the Catholic bishops, whose foreign nationality was essential to the Protectorate's operations and usefulness. French authorities in China also continued to press Chinese officials for the protection of Catholic missions and the punishment of anyone who inflicted injury on the missions. The new bishop in Beijing assured the Vatican in early 1906 that the French minister in China was instructed by Paris to continue protection for all Catholic missionaries and their work, in accordance with the France's traditional policy. ${ }^{30}$ However, the French system was under challenge, as Catholic voices for a new dispensation became more audible. In addition, at this point until the 1911 Revolution (辛亥革命), which resulted in the overthrown of the Qing and the establishment of the Republic of China, the violence that had targeted Chinese Christians meant the protectorate's intervention with the Chinese authorities was no longer salient. On the eve of the 1911 Revolution and in its immediate aftermath, although the French legation reaffirmed its consular instruction that "France was still continuing to assume the protection of Catholic missions in China, without discriminating by nationality." ${ }^{\prime \prime}$, missionaries faced danger to their persons and property most often due to more general social disorder and the prevalence of banditry.

Not long thereafter, the assassination of Archduke Franz Ferdinand of Austria, heir to the throne of Austria-Hungary, by Yugoslav nationalist Gavrilo Princip in Sarajevo on 28 June 1914 triggered World War I. The assassination set off a diplomatic crisis when Austria-Hungary delivered an ultimatum to the Kingdom of Serbia and, as a result, entangled international alliances, formed over the previous decades, were invoked. Within weeks the major powers were at war, and the conflict soon spread around the world. The war drew in all the world's great economic powers, assembled in two opposing alliances: The Allies (based on the Triple Entente of the Russian Empire, the French Third Republic, and the Greater Britain) versus the Central Powers of Germany and Austria-Hungary. Although Italy

27 Pichon, 3 June 1899: "the creation of spheres of influence inevitably runs counter to [the protection of missions] ... It will become less and less easy to give indications to the Chinese government of possible military interventions on our part to bring justice to our protégé." Documents diplomatiques francaus (1871-1914), 1st series, vol. 16, p. 336. The English translation was quoted in (Young 2013, p. 79).

28 Louis Ratard (acting concul-general) to Delcassé, Shanghai, 27 July 1901: Archives du Ministère des Affairs Etrangères, n.s. 327.

29 Delcassé to French ambassador in Constantinople and the French ministers in Beijing and Cairo (n.d): Archives du Ministère des Affairs Etrangères, n.s. 312.

30 S. Jarlin to Gotti (Propaganda perfect), Beijing, 13 February 1906: Pro A, vol. 490, p. 237r.

31 Beauvais (consul in Guangzhou) to Conty (minister in Beijing), \#75, Guangzhou, 20 March 1913: Archives Diplomatiques de Nantes, documents of the French legation in Beijing, file box 59. 
had been a member of the Triple Alliance alongside Germany and Austria-Hungary, it did not join the Central Powers, but entered on the side of the Entente powers. Following the war, during the Paris Peace Conference of 1919, the Big Four victorious powers (Britain, France, the United States and Italy) imposed their terms in a series of treaties. In this context, the Roman Question became a problem that every side would like to make use to impede from the benefits of Italian.

\section{A Solutions from China? The Refraction of Europe in Zi-ka-wei}

The same year, the Church devised a new strategy to separate the Congregation of the Oriental Churches from the former Congregation de Propaganda Fide. Through this separation, the Pope was attempting to solve the Roman Question through altering its path in "the East"; interest in the "Eastern world" may become a bargaining chip in the ownership of Rome. However, a papal pronouncement on Catholic missions in November 1919 was surely prompted by a variety of circumstances. At the same time, an ever-louder voice for change was emerging from the China mission field. Moreover, there was the particular effect of the European war; the wartime circumstances highlighted the fragility of dependence on foreign powers for the future of Catholicism in the non-western world. More particularly, the reliance of so many Catholic missions on France looked increasingly foolhardy, given French opposition to change and French exhaustion from the war. In addition, most importantly, the Pope was motivated to find in the missions a vehicle for a greater insertion of the Vatican into the world affairs.

Pope Benedict XV (1914-1922) embarked on a comprehensive reorientation of mission work. $\mathrm{He}$ endeavored to change the prevailing situation in the mission fields, against which the Popes had been struggling for several decades. Particularly, the Pope was determined to weaken the close ties between foreign national interests and Catholic missionary interests, to liberate the mission from the burden of colonialism and to focus once again on the supra-nationality of the Church and its mission $^{32}$. On 30 November 1919, the Pope issued the Apostolic Letter (Lettre apostolique) Maximum illud (《夫至大》, the Chinese name of the Letter came from the first three words) ${ }^{33}$. As Belgian scholar Claude Soetens discusses, the papal letter particularly targets China ${ }^{34}$. Two major points from the letter focus on the primary responsibilities of those in charge of the missions, stating that those responsibilities are raising and training a clergy recruited from the native population. The letter points out that this has long been papal policy:

Yet, notwithstanding the Roman Pontiff's insistence, it is sad to think that there are still countries where the Catholic faith has been preached for several centuries, but where you will find no indigenous clergy, except for an inferior kind ... nations which for many centuries have come under the salutary influence of the Gospel and the Church, and have yet been able to yield neither bishops to rule them, nor priests to direct them. Therefore, to all appearances, the methods used in various places to train a clergy for the missions have up to now been defective and distorted. ${ }^{35}$

The Pope excoriates any tendency to serve the "earthly glory and power" of one's own country over the "divine task" of spreading the gospel:

Suppose the missionaries then to be in any way preoccupied with worldly interests, and, instead of acting in everything like an apostolic man, to appear to further the interests of his own country, people will at once suspect his intentions, and may be led to believe that the Christian religion is the exclusive property of some foreign nation; that adhesion to this religion implies submission to a foreign country and the loss of one's own national dignity.

\footnotetext{
32 See (Tiedemann 2010, pp. 571-86)

33 See (Benedict XV 1919).

34 See (Soetens 1997).

35 See (Cummins 2016, p. 97).
} 
From the time of the Opium War, the Jesuits were trying to have Lazarists remove. In respond, Rome's vigorous proactive approach was to a considerable extent inspired by a small group of outspoken foreign missionaries and Chinese priests who came together since 1900 around the Lazarists Antonio Cotta (汤作霖) and Vincent Lebbe (雷鳴遠). French diplomats in China were alerted to the Propaganda Fidei's moves regarding Cotta and Lebbe. The French minister suggested that the government in Paris take advantage of the pressure it put upon a congregation with its motherhouse in France to exile Cotta from China, and that the Belgian government be "mobilized" to persuade the Vatican to remove Lebbe. They both had in his view collaborated in the effort to break the French protectorate and to indigenize China's Catholic Church, and their work brought the condition of the church in China to the attention of the Vatican.

In this situation, the new pope, Pius XI, decided to intervene by naming an Aposolic delegate who would visit China with papal authority behind him. The appointment went to Celso Constantini (剛恒毅, 1876-1958) in November 1922, a few months after the plan to dispatch an apostolic delegate was put into effect. Costantini wasted no time in dealing with crucial issues ${ }^{36}$, among which the elimination of the French Protectorate carried the most tension. Costantini's first assignment was to accomplish a nationwide meeting of Catholic leadership. He proceeded to do so and he chose Zi-ka-wei, Shanghai for "The First Chinese Council", recorded as the Primum Concilium Sinense, to take place in mid-May 1924. Indigenization of the Chinese Catholic church still had a long way to go, but Costantini persisted in the Vatican's agenda, as long as he was supported from Rome ${ }^{37}$.

1929 was the year of the Lateran Pacts. After a sixty-year standoff, the Vatican reconciled with the Italian state. By then, after several years of the Church encouraging the indigenization policy an increasing number of local clergymen were working in Zi-ka-wei compound with less French color and ethnicity. The multiple institutions in Zi-ka-wei were not as functional as they had been before 1900, however, because they were now not supported materially either by the Vatican or by France.

This was the time in which when the Hospice of the Sisters of the Good Shepherd mentioned at the beginning of this paper was founded. By 1930, the Catholic compound was no longer being expanded by the French, whether they were French Jesuits or from other French orders. Yet the Sisters as a French female order arrived in Shanghai at this sensitive point. The Hospice aimed at educating the prostitutes who were misbehaving and protecting homeless females from being mistreated. As an institution run by a female religious order, it should have been situated in an appropriate part of the concentrated complex. Nevertheless, the location of the Hospice was at the far end of the Zhaojia Canal, or to be more specific, in the territory of the French Concession instead of within the scope of Zi-ka-wei, though it was still on the east side of the River.

\section{Concluding Remarks}

The French Protectorate had an array of significant opponents, including various foreign powers, the Chinese officials and the Pope. In contemplating the French Religious Protectorate and the character of the Catholic compound in Zi-ka-wei Shanghai in the 19th and early 20th centuries, some features stand out. One was that the pact between Catholic missions and representatives of the French government in China was never formally specified. It was a product of French arms and diplomacy with a primary task of preventing the Vatican from establishing any similar organization. The protectorate was generally popular in France during the mission's history, however. It was another feature of the Protectorate that it depended on a foreign Catholic episcopate to justify the interventions. Another noteworthy feature of this drama was the tension of the conflict between the defenders of the status quo and the reformers. This time which was which was difficult to define in the ever-changing

36 The crucial issues, namely (1) the reduction of tension between foreign and Chinese Priests; (2) the phased transfer of mission territory to the Chinese clergy; and (3) the elimination of the French Protectorate. See (Tiedemann 2010, pp. 571-86).

37 See (Wu 2018, pp. 165-87). 
diplomatic background. The position of France in the contemporary China was constructed from the mid-19th century onward due to the measure out of Catholic, especially the Jesuits, appeals for help, which formed the occasions for extending France's influence as a leading foreign power in the contemporary context.

The reception of the French Protectorate in early 20th century was more complicated. Conflicts of the status quo inside the missions gained volume. In the first instance, the French Protectorate contributed to the embitterment of Sino-foreign relations. In addition, the various calls for the Catholic church to distance itself from French policy evoked distinct compaign by French officials and by the Vatican, which led to the new Hospice slight locationally separation from the female religious sector of the Zi-ka-wei compound.

The compliment towards Zi-ka-wei in the 1930s as an "Oriental Vatican" was a consequence under the scheme of the Vatican. As a key foundation of the Catholic Church in the Far East, Zi-ka-wei, if it were marked as belonging to the Vatican, would extend the power of the Pope. The question arises: was doing so an attempt to solve the Roman Question through exerting the influence of the Vatican in Asia?

The practical function of the Hospice never ended, even during the Cultural Revolution (1966-1976): based on its original purpose, it was eventually transformed into a hospital for women and infants only. My aim has been to provide a new perspective for the study of female Catholic religious and social philanthropy in Shanghai by placing it in the context of post-Opium War Jesuit strategy at Zi-ka-wei.

Funding: China State Scholarship No. 201708310074; Malatesta Scholarship of 2017 sponsored by Ricci Institute, University of San Francisco.

Conflicts of Interest: The author declares no conflict of interest.

\section{References}

Benedict XV. 1919. Maximum Illud: Apostolic Letter on the Propagation of the Faith throughout the World. Translated by Thomas J. M., and Burke S.J.. Available online: https://www.svdcuria.org/public/mission/docs/encycl/ mi-en.htm (accessed on 15 January 2011).

Brockey, Liam Matthew. 2007. Journey to the East: The Jesuit Mission to China, 1570-1724. Cambridge: Belknap Press of Harvard University.

Brook, Timothy, and Gregory Blue. 1999. China and Historical Capitalism: Genealogies of Sinological Knowledge. Cambridge: Cambridge Univerisity Press.

Cannone, Domenico. 1987. Lèvangelizzazione della provincia cinese del Ho-non nella seconda metà del secolo XIX. Naples: Pontificio Instituto Missioni Estere.

China. Hai guan zong shui wu si shu. 1917. Treaties, Conventions, etc., between China and Foreign States; Shanghai: Statistical Department of the Inspectorate General of Customs.

Cummins, J. S. 2016. Christianity and Missions, 1450-1800. New York: Routledge.

d'Elia, Pasquale M. 1927. Catholic Native Episcopacy in China: Being an Outline of the Formation and Growth of the Chinese Catholic Clergy, 1300-1926. Shanghai: Tòu-Sè-Wè Press, p. 50.

Dunne, George H. 1962. Generation of Giants: The Story of the Jesuits in China in the Last Decades of the Ming Dynasty. Notre Dame: University of Notre Dame Press.

Gernet, Jacques. 1985. China and the Christian Impact. Translated by Janet Lloyd. Cambridge: Cambridge University Press.

Howard, Michael. 1991. The Franco-Prussian War: The German Invasion of France 1870-1871. New York: Routledge.

La Servière, Joseph de. 1925. La nouvelle mission de Kiang-nan (1840-1922). [The new Jiang-nan mission (1840-1922)]. Shanghai: Impromerie de la Mission, Orphelinat de T'ou-sè-wè, Zi-ka-wei.

Lacouture, Jean. 1991. Jésuites: Une multibiographie: Les Conquérants. Paris: Seuil.

Menegon, Eugenio. 2009. Ancestors, Virgins, and Friars: Christianity as a Local Religion in Late Imperial China. Cambridge: Harvard University Asia Center. 
Molony, John, and David Thompson. 2006. 10: Christian Social Thought; A: Catholic Social Teaching. In World Christianities c. 1815-c.1914. Cambridge History of Christianity. Vol.8. Edited by Sheridan Gilley and Brian Stanley. Cambridge: Cambridge University Press.

Pfister, Louis. 1932. Notices biographiques ET bibilographiques sur les Jésuites de l'ancienne mission de Chine, 1552-1773. Shanghai: Imprimerie de la Mission Catholique, vol. I.

Schapiro, J. Salwyn. 1921. Modern and Contemporary European History (1815-1921). Cambridge: The Riverside Press. Soetens, Claude. 1997. LÈglise catholique en Chine au XXe siècle. Paris: Editions Beauchesne, pp. 104-5.

Song, Haojie, ed. 2005. Zikawei History [历史上的徐家汇]. Shanghai: Shanghai Culture Publishing House.

Tiedemann, R. G. 2010. Handbook of Christianity in China. Leiden: Brill Publisher, vol. 2.

Waley-Cohen, Joanna. 2006. Culture of War in China: Empire and the Military under the Qing Dynasty. New York: St. Martin's Press.

Worcester, Thomas, ed. 2017. The Cambirdge Encyclopedia of the Jesuits. Cambridge: Cambridge University Press. $\mathrm{Wu}$, Albert. 2018. In the shadow of empire: Josef Schmidlin and Protestant-Catholic Ecumenism before the Second World War. Journal of Global History 13: 165-87. [CrossRef]

Xiao, Yihua, ed. 1997. Record of Xuhui District. Shanghai: Shanghai Academy of Social Science Press.

Young, Ernest P. 2013. Ecclesiastical Colony: China's Catholic Church and the French Religious Protectorate. New York: Oxford University Press.

(c) 2018 by the author. Licensee MDPI, Basel, Switzerland. This article is an open access article distributed under the terms and conditions of the Creative Commons Attribution (CC BY) license (http://creativecommons.org/licenses/by/4.0/). 